\title{
REPARAÇÃO JURÍDICA E DIREITO À MEMÓRIA: O PAPEL DAS SENTENÇAS CONDENATÓRIAS INTERNACIONAIS E ESTRANGEIRAS SOBRE DESAPARECIMENTOS FORÇADOS
}

\author{
Legal redress and the right to memory: the role of \\ international and foreign enforced disappearance \\ conviction sentences
}

\author{
Melissa Martins Casagrande* \\ Ana Carolina Contin Kosiak**
}

\begin{abstract}
RESUMO
$\mathrm{O}$ artigo propõe que sentenças condenatórias referentes às violações de direitos humanos cometidas em períodos ditatoriais têm um duplo papel de prover reparação jurídica às vítimas e/ou aos seus familiares como também de produção de meios documentais que permitem o acesso ao passado e contribuem para a consolidação do direito à memória. $\mathrm{O}$ recorte que embasa a análise é o da atuação transnacional da Operação Condor no desaparecimento forçado de opositores dos regimes ditatoriais na América do Sul nos anos 60 a 90 . O trabalho analisa jurisprudência comparada (em jurisdições da América do Sul e da Europa) e internacional (Corte Interamericana de Direitos Humanos) acerca de desaparecimentos forçados em contextos repressivos.
\end{abstract}

\footnotetext{
* Professora no Programa de Pós-Graduação em Direito da Universidade Positivo (PPGD/UP) e nos Cursos de Direito e Relações Internacionais da Universidade Positivo. Pós-Doutoranda no Programa de PósGraduação em Direito da Universidade Federal do Paraná (PPGD/UFPR). Doutora em Direitos Humanos e Pluralismo Jurídico pela McGill University, Canada. E-mail: melissa.martinscasagrande@gmail.com. ORCID: https://orcid.org/0000-0003-3637-4242.

** Mestranda no Programa de Pós-Graduação em História da Universidade Federal do Paraná (PPGHIS/UFPR) e do Programa de Pós-Graduação em Direito da Universidade Positivo (PPGD/UP). Email: anac.kosiak@gmail.com.
} 
Palavras-chave: direito à memória; sentenças condenatórias; desaparecimentos forçados.

\begin{abstract}
The article proposes that conviction sentences related to human rights violations committed during dictatorial periods have a double role in promoting legal redress to the victims and/or their families as well as in yielding documental resources that enable access to the past and contribute to the consolidation of the right to memory. The transnational practices of Operation Condor related to enforced disappearances of opposers of the dictatorial regimes in South America between the 60s and $90 \mathrm{~s}$ mainstream the analysis proposed. The paper analyses comparative case law (jurisdictions on South America and Europe) and international case law (Interamerican Court of Human Rights) regarding enforced disappearances in repressive contexts.
\end{abstract}

Keywords: right to memory; conviction sentences; enforced disappearances.

\title{
Introdução
}

Durante a segunda metade do século XX, os Estados latinoamericanos vivenciaram rupturas institucionais, regimes autoritários e graves violações aos direitos humanos. Os abusos estatais e as práticas repressivas geraram sequelas e consequências ainda presentes na justiça e política nesses Estados. A necessidade de reparação, a publicidade e acesso público de documentos, assim como uma ampla e significativa política de memória e de acesso à verdade, são temas que merecem destaque e vêm sendo retomados, principalmente, a partir de decisões judiciais.

Este artigo propõe uma discussão acerca dos crimes de desaparecimento forçado praticados no contexto da Operação Condor, uma rede de violência e colaboração transnacional; e de que forma esses crimes têm sido abordados por decisões judiciais estrangeiras e internacionais que condenam as práticas repressivas dos Estados.

O crime de desaparecimento forçado é compreendido como a violação complexa de direitos fundamentais, alguns inderrogáveis, praticada por agentes públicos (geralmente os encarregados da segurança 
e/ou cumprimento das normas jurídicas), em que, de forma arbitrária, violenta e à margem da lei, detém, encarceram e, não raras vezes, assassinam pessoas, não informando os fatos, o paradeiro da vítima ou a motivação da ação a quem de direito. Trata-se, desse modo, em qualquer situação ou circunstância, de um crime injustificável contra o direito à vida, à liberdade e à segurança pessoal, composto mediante tortura ou tratamento, pena ou castigo cruéis e apartado do devido processo legal. Os ofensores (diretos ou indiretos) aos direitos fundamentais implicados são justamente os encarregados de garanti-los na entidade estatal (Resolução da Assembleia Geral 33/173, de 1978).

A metodologia que embasou o processo de pesquisa e escrita foi a análise de jurisprudência nacional, internacional e comparada (estrangeira) sobre as violações de direitos humanos, sobretudo os casos envolvendo o crime de desaparecimento forçado, cometidas nos contextos repressivos. Discute-se, então, sobre os argumentos e os parâmetros estabelecidos pela legislação e jurisprudência estrangeira e internacional para responsabilizar os Estados pelos abusos cometidos, para condenar aqueles que são individualmente criminalmente responsáveis pela perpetração do crime de desaparecimento forçado; e também de que forma são aplicados os instrumentos internacionais que buscam a prevenção desse tipo de conduta e a reparação por direitos violados.

Objetiva-se demonstrar que as sentenças e a jurisprudência internacional sobre os crimes cometidos durante o período das ditaduras na América Latina, além de buscarem a reparação, via judicial, às vítimas e suas famílias, também produzem meios documentais que permitem o acesso ao passado e contribuem para a consolidação do direito à memória.

\section{Operação Condor}

A Operação Condor (também conhecida como Plan Cóndor ou Operativo Cóndor), iniciativa colaborativa entre os regimes ditatoriais do Cone Sul da segunda metade do século XX, foi uma articulação/organização transnacional cujo principal objetivo era a troca de prisioneiros e informações sobre os diversos movimentos de oposição 
existentes durante o período. O ano-marco de sua formação foi 1975, a partir de então, ações militares conjuntas foram realizadas por Argentina, Bolívia, Brasil, Chile, Paraguai e Uruguai. Em 1978, Peru e Equador também passaram a atuar nessa iniciativa transnacional (MARMONTEL, 2014, p. 113).

A atuação da Operação Condor teve três fases distintas, que demonstram sua complexidade e ao tipo de trabalho que nela se desenvolvia. Em um primeiro momento, no início dos anos 1970, a Operação dedicou-se ao armazenamento de informações em um banco de dados comum sobre pessoas e organizações consideradas subversivas, suspeitas de vínculos com o comunismo ou de desenvolverem atividades contra os regimes militares (CNV, 2014, p. 222). A partir de 1974, a operação inicia sua segunda fase - oficializada em 1975. A sua ação repressiva foi elevada com a presença de ações militares altamente secretas e violentas (MARMONTEL, 2014, p. 123). Na terceira e última fase, o grau de violência foi intensificado e a operação atingiu níveis ainda maiores de transnacionalização com a formação de grupos especiais nos Estados ${ }^{1}$-membros da aliança, que viajavam para, inclusive, outros continentes, objetivando eliminar militantes e simpatizantes pertencentes às organizações políticas clandestinas com atuação no território dos partícipes da Operação (MARMONTEL, 2014, p. 125).

Após a descoberta e abertura dos Archivos del Horror ${ }^{2}$, em 1992 no Paraguai, a historiografia conseguiu reconstruir as atividades criminosas desta aliança repressiva, que se baseava na propagação do terror e em práticas tipificadas como crimes, como, por exemplo: o desaparecimento

$1 \mathrm{O}$ artigo foi escrito a partir de uma perspectiva de análise do Direito, sobretudo do Direito Internacional e a palavra Estado é utilizada por ser a terminologia que, embora também questionável, menos suscita múltiplas interpretações como país, nação ou pátria.

2 Sobre o tema, é importante ressaltar a atuação do advogado paraguaio Martin Almada, responsável pela descoberta das fontes documentais da Operação Condor. Utilizando-se de sua prerrogativa profissional, Almada conseguiu acesso à propriedade em que se situava a Direção Nacional de Assuntos Técnicos, lugar que escondia a sede da Liga Anticomunista do Paraguai, e onde pessoas eram presas e torturadas durante o contexto da Operação Condor. Defensor de direitos humanos na América Latina, a atuação do advogado dialoga com a questão da recuperação da memória dos crimes cometidos pelas ditaduras do Cone Sul, e também com a criação de lugares de memória - como, por exemplo, com a criação do Museu da Memória: Ditadura e Direitos Humanos, no Paraguai, onde é possível encontrar o rol documental sobre a Operação. Ver: http://www.martinalmada.org/ 
forçado de pessoas, torturas, sequestros (inclusive de crianças) e voos da morte. $^{3}$

Em 1992, foram encontrados na cidade de Lambaré, vinte quilômetros a oeste de Assunção, Paraguai, os arquivos do Departamento de Investigação da Polícia da Capital conhecidos como "Arquivos do Terror", totalizando 593 mil páginas microfilmadas, correspondentes a diários, arquivos, fotos, fichas, relatórios e correspondência secreta das ditaduras do Cone Sul (CNV, p. 221). O acervo documental Archivos del Terror, ou Archivos Cóndor, localizado no Centro de Documentación y Archivo, em Asunción, no Paraguai revela uma parcela das origens da Operação Condor. Em dezembro de 1992, descobriu-se um vasto conjunto de documentos da polícia secreta paraguaia sobre a ditadura de Stroessner.

Segundo Dinges (2005, p. 351-352), essa descoberta "é, de longe, a maior coleção de documentos anteriormente secretos da força de segurança de qualquer um dos países" da Operação Condor. Na época do funcionamento da Operação Condor os militares eram obrigados a registrar cada ação ou decisão relativa ao combate à subversão em seus Estados, como revela o acervo documental paraguaio. Armazenaram-se milhares de passaportes de nacionais e estrangeiros, fotografias, relatórios diversos sobre encarceramentos e também o nome de indivíduos que constavam como desaparecidos, entre outros documentos. A análise de alguns desses registros, disponíveis online, foi fundamental para rastrear ao menos uma parcela das origens, dos fundamentos, dos objetivos, das vítimas e de outras características pertinentes à Operação Condor.

\footnotetext{
3 Os chamados voos da morte (conhecidos como vuelos de la muerte, por terem sido práticas comuns nas ditaduras argentina e chilena, principalmente), foram práticas repressivas em que presos políticos eram atirados no rio da Prata ou no mar com a finalidade de ocultar vestígios dos crimes cometidos pelas ditaduras civil-militares latino-americanas (CNV, 2014, p. 409). Verbitsky, em sua obra Vuelos, apresenta, através de relatos e confissões de Adolfo Scilingo, oficial da marinha argentina no período da ditadura, a dinâmica dos voos. Há uma descrição sobre a prática: Eran llevados a la enfermería del sótano, donde los esperaba el enfermero que les aplicaba una inyección para adormecerlos, pero que no los mataba. Así, vivos, eran sacados por la puerta lateral del sótano e introducidos en un camión. Bastante adormecidos eran llevados al Aeroparque, introducidos en un avión que volaba hacia el sur, mar adentro, donde eran tirados vivos. (VERBITSKY, 1995, p. 49). Tradução livre: Eram levados à enfermaria no porão, onde o enfermeiro os esperava e aplicava uma injeção para adormecê-los - mas que não os matava. Assim, vivos, eram jogados pela porta lateral do porão, e introduzidos em um caminhão. Bastante adormecidos, eram levados ao Aeroparque, colocados em um avião que voava rumo ao sul, mar adentro, de onde eram atirados vivos..
} 
É possível perceber grande influência dos ideais da Doutrina da Segurança Nacional (DSN) na condução das atividades da Operação. A DSN foi uma formulação teórica que decorreu da ideia de defesa do Estado de sua população. No contexto brasileiro, é a partir da Escola Superior de Guerra $^{4}$ que o termo passa a ser definido por uma teoria calcada na defesa do Ocidente, do trabalhador nacional e da proteção interna e externa do país contra o "inimigo" (comunista, em especial) (KENICKE, 2016, p. 30). A doutrina ganhou projeções não somente no âmbito militar, mas em muitos outros setores da sociedade, com o objetivo principal de tornar os países latino-americanos em potências militares e econômicas.

$\mathrm{O}$ conceito de segurança nacional operacionaliza-se a partir do momento em que se define o inimigo que, portanto, "está, ao mesmo tempo dentro e fora do país", pois a segurança nacional desfaz a distinção entre política externa e política interna (COMBLIN, 1978, p. 55). Nesse sentido, reitera-se a opção da reunião dos Estados em uma estrutura repressiva própria, com atuações tanto a nível interno, como, principalmente, no externo, a partir do colaboracionismo transnacional entre as ditaduras.

A Operação foi marcada pelos desaparecimentos, perseguições, extermínio político e outras ações tipificadas como crimes contra humanidade pelo Direito Internacional. Mesmo assim, tanto a historiografia, como os tribunais e a sociedade civil organizada que atua na defesa dos direitos humanos e na denúncia dos crimes cometidos durante as ditaduras do Cone Sul, ainda enfrentam muitos desafios relacionados à responsabilização dos agentes, às anistias impostas durante os períodos de transição, ao acesso à documentação e aos fatos, bem como em relação à tipificação penal dos crimes e a interpretação conflitante entre o direito interno dos Estados e a jurisprudência das Cortes internacionais.

Entretanto, é importante ressaltar que, mesmo a curtos passos, algumas decisões vêm sendo tomadas no âmbito jurídico, no sentido de responsabilizar os agentes das ditaduras e também atualizar a interpretação sobre os crimes nelas realizados. Segundo o relatório final da Comissão Nacional da Verdade (CNV) do Brasil, um dos processos judiciais mais

6 Inaugurada em 1949, e sob a influência do National War College (EUA), a Escola foi instituída para servir como centro de altos estudos estratégicos do Estado brasileiro; com o intuito de desenvolver e consolidar os conhecimentos necessários para o planejamento da segurança nacional (FERNANDES, 2009, p. 841). 
noticiados sobre a Operação Condor foi aberto em Roma, Itália, no final de 2007. No rastro de vítimas com nacionalidade italiana no Cone Sul, a promotoria trabalhou anos para construir sua argumentação contra os principais atores das ditaduras da região. A denúncia foi aceita em 27 de dezembro de 2007 e foram emitidas ordens de prisão contra 146 pessoas, entre ministros militares, chefes de serviços secretos e policiais de seis Estados participantes na Operação Condor (Brasil, Argentina, Uruguai, Bolívia, Peru e Paraguai), entre os quais 61 argentinos, 22 chilenos, 32 uruguaios, sete bolivianos, sete paraguaios, quatro peruanos - e 13 brasileiros (CNV, 2014, p. 268).

\subsection{Operação Condor e a Justiça Italiana}

Em 8 de julho de 2019, o Tribunal de Apelação de Roma emitiu sentença ${ }^{5}$ em relação ao caso, condenando 24 pessoas à prisão perpétua por seus envolvimentos na Operação Condor. O julgamento começou em 2015 e se concentrou na responsabilidade de altos funcionários das ditaduras [civil] militares do Chile, Paraguai, Uruguai, Brasil, Bolívia e Argentina pelo assassinato e desaparecimento de 43 pessoas, incluindo 23 pessoas de nacionalidade italiana. Entre os condenados estão Francisco Morales Bermúdez, presidente do Peru entre 1975 e 1980; Juan Carlos Blanco, exministro das Relações Exteriores do Uruguai; Pedro Espinoza Bravo, exvice-chefe de inteligência no Chile; e Jorge Néstor Fernández Troccoli, uruguaio, ex-oficial de inteligência naval e que reside na Itália (THE GUARDIAN, 2019).

7 A sentença ainda não foi publicada em sua totalidade, e, até o momento, é a imprensa que ocupa o papel principal de publicizar e narrar esse fato. Segundo o jornal Brasil de Fato, "a íntegra da sentença, com as justificativas, será publicada em 90 dias, mas, ao que tudo indica, a Corte aceitou um dos principais argumentos defendidos tanto pela advocacia do Estado da Itália, quanto pelo Ministério Público, isto é, que os sequestros cometidos por ex-militares e agentes de serviços de inteligência eram finalizados com a morte das vítimas". Disponível em: https://www.brasildefato.com.br/2019/07/08/operacao-condor-justica-daitalia-condena-mais-24-a-prisao-perpetua 
A imprensa italiana também noticiou sobre a decisão. O jornal Repubblica intitulou a matéria noticiando a emissão da sentença como "Operação Condor, quando a América do Sul se tornou o subcontinente dos ditadores" $"$ e reiterou que a coordenação dos serviços de inteligência também se baseou na cumplicidade e conivência da Central Intelligence Agency (CIA por sua sigla em inglês), a agência civil de inteligência dos Estados Unidos da América e do Federal Bureau of Inteligence (FBI por sua sigla em inglês), unidade de polícia do Departamento de Justiça dos Estados Unidos ${ }^{7}$ (REPUBBLICA, 2019). Além disso, a imprensa italiana tornou público parte do posicionamento dos promotores que atuaram na causa, reiterando que "as apreensões [da Operação Condor] não nasceram apenas para extorquir informação, mas para matar. E os assassinatos eram planejados para eliminar provas, e também serviam de aviso para os que ficaram, com o intuito de que desistissem da luta subversiva". Ainda no que diz respeito à atuação da promotoria ${ }^{8}$, apresentou-se o argumento de que "os 24 acusados contribuíram para um plano que levou a um trabalho devastador de extermínio da oposição, em que a eliminação física do subversivo era prevista desde o início" (IL FATTO QUOTIDIANO, 2019).

No Brasil, a notícia da condenação dos membros da Operação Condor foi publicada por vários meios de comunicação da imprensa escrita, sem aparente incômodo político ou grandes manifestações - até mesmo por parte de pessoas próximas à temática da ditadura, como membros de grupos de defesa dos direitos humanos, por exemplo. Mesmo que não existam brasileiros condenados nesta sentença, é fato notório que a contribuição do Brasil foi efetiva para a atuação da Operação e que sua estrutura foi

8 Tradução livre. Operazione Condor, quando il Sudamerica diventò il subcontinente dei dittatori.

9 Segundo a publicação italiana, a Operação Condor foi a coordenação secreta entre os serviços de inteligência das ditaduras [civil] militares do Cone Sul para combater as forças esquerdistas na América Latina, e que possuía objetivos compatíveis com a política anticomunista dos EUA.

8 Tradução livre. Accolte in toto le richieste dell'accusa sostenuta dal pg Francesco Mollace e dalla pm Tiziana Cugini che davanti ai giudici aveva sottolineato: "I sequestri non nascevano solo per estorcere informazioni, ma per uccidere. E le uccisioni le avevano programmate per eliminare prove e perché fossero monito per quanti rimanevano, affinché desistessero dalla lotta sovversiva". I 24 imputati, secondo Mollace, "hanno contribuito a un piano che ha portato a una devastante opera di sterminio delle opposizioni. Un piano in cui l'eliminazione fisica del sovversivo era prevista fin dall'inizio". 
construída com o auxílio da inteligência brasileira. Reitera-se, portanto, que a publicação de sentenças como esta são relevantes para a produção de meios documentais de registro do período ditatorial e, especificamente, da atuação da Operação Condor.

Argumenta-se que a sentença pode ser um importante documento de discussão sobre os crimes perpetrados pela Operação Condor, principalmente quando se trata dos desaparecimentos forçados e da compreensão internacional desse crime. Entretanto, ela também influencia a discussão da memória das ditaduras do Cone Sul, dado que seu caráter é também reparatório - no sentido de as condenações terem ocorrido no mínimo 40 anos depois de terem sido perpetrados. ${ }^{9}$

Nesse sentido, este artigo procura discutir, a partir do objeto da sentença da Corte italiana e dos parâmetros estabelecidos pela legislação e jurisprudência internacionais, os conceitos do crime de desaparecimento forçado e os entendimentos jurisprudenciais e normativos internacionais sobre o crime, além de questionar (a falta de) posicionamento brasileiro sobre essa questão. Além disso, em momentos de revisita às temáticas de análise sobre as ditaduras do Cone Sul, é importante ressaltar novas formas de pesquisa que contemplam a historiografia denominada de história recente. Assim, as sequelas das violações massivas de direitos humanos perpetradas durante os regimes ditatoriais e o impacto destas questões nas memórias socias tornam a chave memorialística mais visível na agenda historiográfica, que possui intensa relação com os modos de se compreender a história e atitudes do presente que ainda são pautadas pelo passado traumático vivenciado pelos países latino-americanos (ÁGUILA \& ALONSO, 2017, p. 15-16).

11 Prova disso é que, da entrevista realizada com Aurora Meloni, cujo marido, Daniel Banfi, fora sequestrado e assassinado em 1974, em Buenos Aires, resultou a seguinte declaração: "nós nunca desistimos, e hoje todos nós vencemos. A decisão de hoje não é apenas para meu marido... a decisão de hoje é dedicada a todas as pessoas mortas e sequestradas pela Operação Condor" (THE GUARDIAN, 2019). Tradução livre. "We've never given up and today we all won. Today's ruling is not only for my husband ... today's ruling is dedicated to all the people killed and kidnapped under Condor". 


\section{O crime de desaparecimento forçado na legislação a jurisprudência internacionais}

Prática recorrente pelas ditaduras do Cone Sul, o desaparecimento assegurou não somente o assassinato físico e simbólico (ao assegurar a morte da própria morte) de pessoas desvinculadas de qualquer militância como fetos, bebês e crianças -, assim como de opositores políticos e integrantes de grupos guerrilheiros, mas também foi um fator determinante para a intimidação e a submissão de setores da sociedade, atingidos direta ou indiretamente pela multiplicação de seus efeitos (BAUER, 2014, p. 37). Utilizando-se os jargões militares, não se tratou de uma guerra convencional, mas uma guerra total e psicológica, concebida desde as ambiguidades e imprecisões nas definições sobre quem era o inimigo até a adoção do desaparecimento como política de eliminação da dissidência (BAUER, 2014, p. 42).

Na Argentina, por exemplo, após o golpe de 1966, surge como forma de repressão política, o desaparecimento: "uma pessoa que a partir de determinado momento desaparece, se esfuma, sem que sobre registro de sua vida ou de sua morte" (CALVEIRO, 2013, p. 38). A partir de 1974, tal modalidade torna-se usual e corriqueira e, em 1975, inicia-se política institucional de desaparecimento de pessoas, que conviveu com o silêncio e o consentimento de diversos setores da sociedade argentina (CALVEIRO, 2013, p. 39).

Decididas sobre o extermínio dos "inimigos", as Forças Armadas argentinas optaram pela prática do desaparecimento, que oferecia uma série de vantagens em relação às outras formas de eliminação, tais como: evitar a reação externa que poderiam produzir os fuzilamentos massivos; evitar a reação interna de uma sociedade despreparada para aplicação massiva ou seletiva da pena de morte; obter enormes vantagens sobre o inimigo; possibilitar a aplicação massiva da pena de morte (incluindo idosos e menores); proteger erros e excessos e evitar ações das vítimas; e diluir responsabilidades futuras (PADRÓS, 2005, p. 653).

Na perspectiva de um ramo de Direito Internacional Público que se molda com o fim de tutelar a dignidade da pessoa humana, de limitar a atuação dos Estados em prol do princípio pro pessoa e também de estimulá-los e auxiliá-los a implementar os direitos humanos em âmbito 
interno, uma gama de instrumentos foi desenvolvida com o objetivo de proteger pessoas contra o desaparecimento forçado.

\subsection{A definição de desaparecimento forçado no Direito Internacional}

O desaparecimento forçado de pessoas como um fenômeno autônomo e não apenas como um conjunto de violações de direitos humanos, vem sendo normatizado no plano do Direito Internacional dos Direitos Humanos e a comunidade internacional tem proposto diversas ações no que se refere à erradicação de tal prática, à proteção de pessoas, à punição dos perpetradores, à localização das vítimas do passado, à reparação dos familiares e da sociedade em geral.

A primeira Resolução da Assembleia Geral da ONU concernente ao desaparecimento forçado de pessoas data de $1978^{10}$. Nesse momento, a comunidade internacional manifestava sua preocupação com a situação do desaparecimento como método de intimação autoritária, que tomava espaço no contexto latino-americano e relegava os familiares de desaparecidos a uma situação de suspenso e de falta de informações. Ademais, expressava a violação direta que o crime exercia a diversos artigos da Declaração Universal de Direitos Humanos e recomendava diversas ações por parte dos Estados, onde tal violação vinha ocorrendo, no sentido de prevenir, investigar e punir a prática reiterada que se desenvolvia naquele momento.

O desaparecimento forçado é o objeto principal de dois tratados internacionais: a Convenção Interamericana sobre o Desaparecimento Forçado de Pessoas, de âmbito regional, e a Convenção Internacional para a Proteção de todas as Pessoas contra o Desaparecimento Forçado, de âmbito global. Ambas são legalmente vinculantes e geram

12 Resolução 33/173 da Assembleia Geral da ONU, adotada na 90a plenária da $33^{\text {a }}$ Sessão, em 20 de dezembro de 1978. 
responsabilização internacional em caso de descumprimento pelos Estadosparte que as ratificam ${ }^{11}$.

A Convenção Interamericana foi aprovada pela Assembleia-Geral da Organização dos Estados Americanos em 1994 e entrou em vigor em $1996^{12}$. A Convenção Internacional foi aprovada pela Assembleia Geral da ONU em 2006 e entrou em vigor em $2010^{13}$. É pacífico o entendimento de que tanto a existência quanto o conteúdo da Convenção Internacional foram fortemente influenciados pela Convenção Interamericana e pelas decisões proferidas no âmbito do Sistema Interamericano de Proteção dos Direitos Humanos ${ }^{14}$.

Um terceiro tratado internacional conceitua o crime de desaparecimento forçado no contexto da eventual responsabilização individual pelo cometimento do crime. O Estatuto de Roma ${ }^{15}$, que

13 Os tratados internacionais, enquanto acordos internacionais juridicamente obrigatórios e vinculantes (pacta sund servanda), constituem hoje a principal fonte de obrigação do Direito Internacional. A primeira regra fixada em relação a eles é a de que os tratados internacionais só se aplicam aos Estados-partes, ou seja, aos Estados que expressamente consentiram em sua adoção.

14 A Convenção Interamericana sobre o Desaparecimento Forçado de Pessoas conta com 16 Estados signatários e 15 ratificantes (até agosto de 2019). Os Estados-parte da Convenção são: Argentina, Bolívia, Brasil, Chile, Colômbia, Costa Rica, Equador, Guatemala, Honduras, México, Panamá, Paraguai, Peru, Uruguai e Venezuela. A Nicarágua assinou o tratado em 1994, mas não apresentou ratificação até agosto de 2019. O Brasil assinou a Convenção em 1994 e ratificou em 2013. O Decreto n. 8766 de 2016 internaliza o tratado ao ordenamento jurídico brasileiro.

15 A Convenção Internacional para a Proteção de todas as Pessoas contra o Desaparecimento Forçado conta com 98 Estados signatários e 61 ratificantes (até agosto de 2019). O Brasil assinou a Convenção em 2007 e ratificou em 2010. Todos os países da América do Sul, exceto Guiana e Suriname, assinaram a Convenção. A Venezuela, embora tenha assinado a Convenção Internacional em 2008, não apresentou ratificação até agosto de 2019.

16 O Sistema Interamericano de Proteção dos Direitos Humanos consiste em dois regimes: o primeiro é baseado na Carta da Organização dos Estados Americanos - OEA (1948) e na Declaração Americana de Direitos e Deveres do Homem (1948) e o segundo tem como premissa os preceitos da Convenção Americana sobre Direitos Humanos (1969) e seu Protocolo Adicional em Matéria de Direitos Econômicos, Sociais e Culturais (1988). Ao entrar em vigor, a Convenção estabeleceu a Corte Interamericana de Direitos Humanos, vigente perante os Estados que a ratificam e que se submetem à sua jurisdição.

17 O Estatuto de Roma conta com 137 signatários e 122 Estados ratificantes até agosto de 2019. O Brasil assinou o tratado em 2000 e o ratificou em 2002. A Emenda Constitucional n. 45 de 2004, incluiu o parágrafo $4^{\circ}$ no artigo $5^{\circ}$ do texto constitucional, que reforça que "o Brasil se submete à jurisdição de Tribunal Penal Internacional a cuja criação tenha manifestado adesão”. A jurisdição do Tribunal Penal 
estabelece o Tribunal Penal Internacional e define sua jurisdição. O Estatuto foi adotado em 1998 e entrou em vigor em 2002. O Estatuto de Roma define desaparecimento forçado como um crime contra a humanidade (art. 7, 1, i) quando cometido no quadro de um ataque, generalizado ou sistemático, contra qualquer população civil, havendo conhecimento desse ataque $($ art. 7,1$)$.

No âmbito do sistema regional de proteção de Direitos Humanos, o desaparecimento forçado é definido pela Convenção Interamericana sobre o Desaparecimento Forçado que dispõe, que entende-se por desaparecimento forçado a privação de liberdade de uma ou mais pessoas, seja de que forma for, praticada por agentes do Estado ou por pessoas ou grupos de pessoas que atuem com autorização, apoio ou consentimento do Estado, seguida de falta de informação ou da recusa a reconhecer a privação de liberdade ou a informar sobre o paradeiro da pessoa, impedindo assim o exercício dos recursos legais e das garantias processuais pertinentes (OEA, 1994, art. 2).

A conceituação presente no Estatuto de Roma é compreendida como a detenção, a prisão ou o sequestro de pessoas por um Estado ou uma organização política ou com a autorização, o apoio ou a concordância destes, seguidos de recusa a reconhecer tal estado de privação de liberdade ou a prestar qualquer informação sobre a situação ou localização dessas pessoas, com o propósito de lhes negar a proteção da lei por um prolongado período de tempo (ESTATUTO DE ROMA, 1998, art. 7, 2, i) ${ }^{16}$. Importante ressaltar que o crime de desaparecimento forçado não aparece diretamente na jurisdição de tribunais penais internacionais antes do Estatuto de Roma (MENDOZA ESCOBAR, 2018, p. 24). Percebe-se, portanto, a relevância das sentenças estrangeiras e internacionais, sobretudo às relativas ao desaparecimento forçado de pessoas na América Latina, para a consolidação e, consequente, codificação em âmbito global do desaparecimento forçado como um crime contra a humanidade.

Por fim, a Convenção das Nações Unidas sobre o Desaparecimento Forçado de Pessoas define desaparecimento forçado

Internacional se aplica à crimes cometidos no território dos Estados-parte, por nacional de Estado-parte ou em outros territórios por solicitação do Conselho de Segurança da ONU.

18 O texto é tradução oficial para o português do Estatuto de Roma, pelo Decreto n. 4.388 de 25 de setembro de 2002 que internaliza o Estatuto de Roma ao ordenamento jurídico brasileiro. 
como a prisão, detenção, sequestro ou qualquer forma de privação da liberdade que seja perpetrada por agentes do Estado ou por pessoas ou grupos agindo com a autorização, apoio ou aquiescência do Estado; e a subsequente recusa em admitir a privação de liberdade ou a ocultação do destino ou paradeiro da pessoa desaparecida, privando-a assim da proteção da lei (ONU, 2007, art. 2). A Convenção informa também que nenhuma circunstância excepcional, seja estado de guerra ou ameaça de guerra, instabilidade política interna ou qualquer outra emergência pública, poderá ser invocada como justificativa para o desaparecimento forçado (ONU, 2007 , art. 1) ${ }^{17}$.

\section{$2.2 O$ desaparecimento forçado na jurisprudência internacional}

O cenário contemporâneo em que o Direito Internacional se insere supera o conceito clássico de soberania, que emerge juridicamente com a Paz de Vestfália e perdura até a Segunda Guerra Mundial e no qual vigorava a inviolabilidade do princípio da não-intervenção em assuntos internos de um Estado. Contemporaneamente, após os processos de humanização do Direito Internacional e internacionalização da proteção dos Direitos Humanos, desencadeados por um desejo de prevenção de atrocidades como as cometidas durante a Segunda Guerra Mundial, a atuação jurídica subsidiária da comunidade internacional prevalece (CANÇADO TRINDADE, 2006). A soberania estatal é relativizada em prol da proteção do ser humano (PIOVESAN, 2013) e famílias de vítimas de desaparecimento forçado passam a poder acionar instâncias internacionais contra o Estado, já que o próprio Estado é o responsável pela grave violação de direitos humanos (PERRUSO, 2010, p. 62).

$\mathrm{O}$ intuito desse artigo é apresentar o duplo papel de sentenças condenatórias no provimento de reparação jurídica e na instrumentalização 
do direito à memória. Além da análise da sentença do Tribunal de Apelação de Roma, caso que mais recentemente trouxe à tona a temática e que constitui sentença proferida dentro do exercício de jurisdição da Itália, de acordo com suas leis nacionais, por crimes cometidos contra nacionais italianos, propõe-se a análise de sentenças internacionais, proferidas pela Corte Interamericana de Direitos Humanos (CorteIDH) ${ }^{18}$, assim como a análise de sentenças estrangeiras proferidas no Cone Sul acerca do tema. ${ }^{19}$

Os primeiros casos de desaparecimento forçado apresentados perante a CorteIDH referem-se a fatos ocorridos em Honduras ${ }^{20}$, nos anos finais da década de 1980 - portanto, anteriores aos instrumentos internacionais citados anteriormente. Em 1987, pela primeira vez, uma Corte Internacional apreciava três casos de desaparecimento forçado de pessoas. Havia grande expectativa quanto a esses julgamentos, pois a CorteIDH deveria se pronunciar acerca de várias questões adicionais ao fenômeno do desaparecimento, o que daria mais substância aos órgãos da ONU para a compreensão da questão. Com o primeiro julgamento dessa jurisdição internacional, estabeleceu-se um precedente quanto à investigação e ajuizamento de um caso de desaparecimento forçado de pessoas, pois a sentença declarou que o desaparecimento forçado constitui

18 A opção metodológica pela análise de casos perante a Corte deve-se a sua jurisdição contenciosa, semelhante aos casos de sentenças estrangeiras e diferente em escopo e natureza jurídica das decisões proferidas pela Comissão Interamericana de Direitos Humanos e pelo Comitê para o monitoramento da Convenção Internacional. Excluem-se também dessa análise os casos sobre desaparecimento forçado analisados pelo Tribunal Penal Internacional já nenhum relaciona-se ao recorte temporal e geográfico deste artigo, ou seja, ditaduras civis-militares na América Latina nos anos 70 e 80.

19 Vale lembrar, nesse contexto, o pedido de extradição ao Reino Unido pela Espanha do ditador chileno Augusto Pinochet em 1998. Pinochet havia viajado para o Reino Unido para tratamento de saúde. O pedido de extradição embasava-se em processo criminal contra Pinochet ajuizado na Espanha por potenciais crimes cometidos contra nacionais espanhóis como parte da Operação Condor. Após 502 dias de prisão (com vistas à extradição), alegando fragilidade do estado de saúde do ex-ditador, o Reino Unido negou o pedido de extradição e Pinochet regressou ao Chile onde faleceu em 2006. O processo, portanto, foi extinto, não havendo consequentemente, sentença condenatória. Ver, por exemplo, https://brasil.elpais.com/brasil/2018/10/16/internacional/1539652824_848459.html.

20 CORTE INTERAMERICANA DE DIREITOS HUMANOS. Caso Velásquez Rodriguez vs Honduras. Mérito. Sentença de 29 de julho de 1988, série C, n. 4. CORTE INTERAMERICANA DE DIREITOS HUMANOS. Caso Fairén-Garbi e Solis-Corrales contra Honduras. Sentença de mérito de 15 de março de 1989. Série C, n. 6. CORTE INTERAMERICANA DE DIREITOS HUMANOS. Caso Godínez-Cruz contra Honduras. Mérito. Sentença de 20 de janeiro de 1989. Série C, n. 5. 
crime contra a humanidade e violação múltipla e continuada de inúmeros direitos humanos e, por isso, as sanções jurídicas não poderiam estar restritas às limitações aplicadas a outros delitos quanto ao marco cronológico (prescrição) (PERRUSO, 2010, p. 28).

No caso Velásquez-Rodriguez contra Honduras, na sentença de 1988, a Corte afirma que, na história da violação dos direitos humanos, os desaparecimentos não são novidade. Mas seu caráter sistemático e reiterado, sua utilização como uma técnica destinada a produzir não só o próprio desaparecimento, momentâneo ou permanente, de determinadas pessoas, mas também, um estado generalizado de angústia, insegurança e temor, são relativamente recentes (CorteIDH, 1988). Mesmo que esta prática possua caráter relativamente universal, na América Latina o desaparecimento forçado apresentou, nos últimos anos, uma intensidade excepcional. $\mathrm{O}$ fenômeno dos desaparecimentos constitui uma forma complexa de violação dos direitos humanos que deve ser compreendida e encarada de uma maneira integral (CorteIDH, 1988).

De acordo com a sentença que faz referência às violações à Convenção Americana de Direitos Humanos, apenas o fato do isolamento prolongado e da incomunicabilidade coativa representa um tratamento cruel e desumano que lesa a integridade psíquica e moral da pessoa e o direito de todo detido a um trato respeitoso da sua dignidade, já configura violação do direito à integridade pessoal (CorteIDH, 1988). Além disso, a mera circunstância de que o sequestro e o cativeiro tenham ficado por conta de autoridades, que comprovadamente submetiam os detidos a vexames, crueldades e torturas, representa a inobservância por parte dos Estados - e, no caso, o Estado de Honduras - da obrigação de respeitar direitos; bem como o dever de garantir o direito à integridade física, moral e mental e a não ser submetido a torturas, nem a penas ou tratos cruéis, desumanos ou degradantes (CorteIDH, 1988).

A CorteIDH conclui que esses fatos, ligados à falta de investigação do ocorrido, representa uma infração de um dever jurídico por conta do Estado de Honduras, de garantir a toda pessoa sujeita à sua jurisdição, a inviolabilidade da vida e o direito a não ser privada da mesma, arbitrariamente, o qual implica a prevenção razoável de situações que possam redundar na supressão desse direito (CorteIDH, 1988).

No caso Fairén Garbi e Solís Corrales contra Honduras, a Corte julgou o pedido improcedente, em razão da falta de provas (não é possível estabelecer que o desaparecimento das pessoas das quais trata o processo 
tenha ocorrido em território hondurenho e, por isso, não podem ser juridicamente imputáveis ao Estado de Honduras). O caso refere-se a nacionais da Costa Rica que, em trânsito pelo território de Honduras, foram dados como desaparecidos. Entretanto, é relevante apontar que a Corte considerou comprovados fatos como a existência de uma prática de desaparecimentos cumprida ou tolerada pelas autoridades hondurenhas entre os anos de 1982 a 1984, sendo estimado um número entre 100 e 150 pessoas desaparecidas - e que esses desaparecimentos tiveram um padrão similar. Além disso, afirma que a população hondurenha reconhece como fato notório que os desaparecimentos eram decorrência de sequestros perpetrados por agentes militares ou por policiais (CorteIDH, 1989).

Ainda, importante ressaltar que a sentença da Corte IDH, no caso Fairén Garbi e Solís Corrales contra Honduras, determina um modus operandi das circunstâncias que envolviam os desaparecimentos forçados: (i) a vítima ser considerada perigosa, pelas autoridades hondurenhas, para a segurança do Estado de Honduras; (ii) as armas empregadas eram de uso reservado das autoridades militares e policiais; (iii) as pessoas sequestradas eram vendadas e conduzidas a lugares secretos e irregularidades de detenção, interrogadas, torturadas e algumas assassinadas e sepultadas em cemitérios clandestinos; (iv) as autoridades negavam a detenção das pessoas; (v) as autoridades policiais, o governo e o Poder Judiciário se negavam a prevenir, investigar e sancionar as condutas (CorteIDH, 1989).

Esses dois casos hondurenhos são emblemáticos pelo ineditismo da atuação da Corte em relação à temática dos desaparecimentos forçados na América Latina, período que coincide com o fim das ditaduras do continente. A caracterização de que o desaparecimento forçado de seres humanos constitui uma violação múltipla e continuada de direitos reconhecidos na Convenção Americana de Direitos Humanos se mantém na jurisprudência da Corte: caso Godínez Cruz contra Honduras (1988); caso Aloeboete e outros contra Suriname (1991); caso Neira Alegría e outros contra Peru (1995); caso Caballero Delgado y Santana contra Colômbia (1995); caso Blake contra Guatemala (1996); caso Castillo Páez contra Peru (1997); caso "Panel Blanca" (Paniagua Morales e outros) contra Guatemala; caso Trujillo Oroza contra Bolivia; caso Durand e Ugarte contra Peru; caso Bámaca Velásquez contra Guatemala (2000); caso Caracazo contra Venezuela; caso Juan Humberto Sánchez contra Honduras; caso Molna Theissen contra Guatemala; caso 19 Comerciantes contra Colômbia (2004); caso Irmãs Serrano Cruz contra El Salvador; 
caso "Masacre de Mapiripán” contra Colômbia; caso Gómez Palomino contra Peru; caso Blanco Romero e outros contra Venezuela; caso Goiburú e outros contra Paraguai; caso La Cantuta contra Peru; caso Heliodoro Portugal contra Panamá; caso Tiu Tojín contra Guatemala; caso Ticona Estrada e outros contra Bolivia; caso Anzualdo Castro contra Peru; caso Gomes Lund e outros (Guerrilha do Araguaia) contra Brasil (2010); caso Gelman contra Uruguai (2011); e caso Vladimir Herzog contra Brasil (2018).

Tratando especificamente sobre graves violações de direitos cometidas no marco da Operação Condor, caso Goiburú e outros contra Paraguai (2006) e caso Gelman contra Uruguai (2011), a Corte estabeleceu que os serviços de informação de vários Estados do Cone Sul formaram, durante a década de 1970, uma organização interestatal complexamente articulada com finalidades criminosas, cujo conteúdo continua sendo revelado ainda hoje (CNV, 2014, p. 220).

A existência da Operação Condor foi reconhecida no caso Goiburú e outros contra Paraguai (2006). Segundo a sentença, a maioria dos regimes ditatoriais na região do Cone Sul assumiu o poder ou esteve no poder durante a década de 1970, o que permitiu a repressão contra pessoas chamadas de "elementos subversivos" transnacionalmente. O apoio ideológico de todos esses regimes era a Doutrina de Segurança Nacional, através dos movimentos de esquerda e outros grupos, eram classificados como "inimigos comuns", independentemente de sua nacionalidade. Neste contexto, ocorreu a chamada Operação Condor, um nome-chave dado à aliança que uniu as forças de segurança e os serviços de inteligência das ditaduras do Cone Sul em sua repressão contra pessoas designadas como "elementos subversivos". Essa operação também foi favorecida pela situação generalizada de impunidade pelas graves violações de direitos humanos que existiam à época, propiciada e tolerada pela ausência de garantias judiciais e instituições judiciais ineficazes para enfrentar ou conter as violações sistemáticas dos direitos humanos por omissão, mas sobretudo por ação de agentes do Estado. Isso está intimamente relacionado com a obrigação de investigar casos de execuções extrajudiciais, desaparecimentos forçados e outras violações graves dos direitos humanos (CorteIDH, 2006).

O caso caso Gelman contra Uruguai (2011), segundo a própria sentença, se reveste por uma particular "transcendência histórica", pois os fatos começaram a se perpetrar em colaboração com autoridades argentinas 
em um contexto de prática sistemática de detenções arbitrárias, torturas, execuções e desaparecimentos forçados pelas forças de segurança e inteligência da ditadura uruguaia no marco da Doutrina de Segurança Nacional e da Operação Condor (CorteIDH, 2011). A mesma sentença afirma que a detenção ou sequestro ilegal ou arbitrário, a tortura e o desaparecimento forçado, foram resultados de uma operação de inteligência policial e militar, planejada e executada clandestinamente pelas forças de segurança argentinas em estreita colaboração com as forças de segurança uruguaias, o que é congruente com o modus operandi da Operação Condor.

Além disso, uma especificidade do caso do desaparecimento forçado de María Claudia García, examinado no caso Gelman contra Uruguai (2011), revela uma particular concepção do corpo da mulher, que atenta contra sua livre maternidade e contra o livre desenvolvimento da personalidade das mulheres. Essa relação identitária se dá, em grande medida, pelo fato de que o desaparecimento forçado de García ocorreu em um contexto de desaparecimentos forçados de mulheres grávidas e apropriações ilícitas de crianças, ocorridos também no âmbito da Operação (CorteIDH, 2011).

A responsabilidade do Estado brasileiro por desaparecimentos forçados no período ditatorial também foi analisada pela CorteIDH. A sentença do caso Gomes Lund e outros (Guerrilha do Araguaia) contra Brasil é emblemática por determinar a responsabilidade do Estado brasileiro e prescrever que o Brasil deve adotar, em um prazo razoável, as medidas que sejam necessárias para tipificar o delito de desaparecimento forçado de pessoas em conformidade com os parâmetros interamericanos. A sentença determina ainda que enquanto cumpre com essa medida, o Estado deve adotar ações que garantam o efetivo julgamento e, se for o caso, a punição em relação aos fatos constitutivos de desaparecimento forçado através dos mecanismos existentes no direito interno. Para a Corte Interamericana de Direitos Humanos, a adequada tipificação do desaparecimento forçado deve incluir: a) a eliminação, $a b$ initio, de instituições jurídicas como a anistia e a prescrição; b) a eliminação da competência da justiça militar; c) a investigação da totalidade das condutas das pessoas implicadas; e d) a determinação das sanções proporcionais à gravidade do crime (CorteIDH, 2010).

Na mesma sentença, o Brasil destacou a futura constituição de uma Comissão Nacional da Verdade. A Corte considerou que se trata de um mecanismo importante, entre outros aspectos, para cumprir a obrigação do 
Estado de garantir o direito de conhecer a verdade sobre o ocorrido. Segundo a decisão, o estabelecimento de uma Comissão da Verdade, dependendo do objeto, do procedimento, da estrutura e da finalidade de seu mandato, poderia contribuir para a construção e preservação da memória histórica, o esclarecimento de fatos e a determinação de responsabilidades institucionais, sociais e políticas em determinados períodos históricos de uma sociedade. Por isso, o Tribunal valorou a iniciativa de criação da Comissão Nacional da Verdade e exortou o Estado a implementá-la, em conformidade com critérios de independência, idoneidade e transparência na seleção de seus membros, assim como a dotá-la de recursos e atribuições que lhe possibilitem cumprir eficazmente com seu mandato. A Corte julgou pertinente, entretanto, destacar que as atividades e informações que, eventualmente, recolha essa Comissão, não substituem a obrigação do Estado de estabelecer a verdade e assegurar a determinação judicial de responsabilidades individuais, através dos processos judiciais penais (CorteIDH, 2010). No ano de 2011, foi aprovada a Lei $n^{\circ} 12.528$, que criou a CNV, com a finalidade de examinar e esclarecer as graves violações de direitos humanos praticadas no período fixado no art. $8^{\circ}$ do Ato das Disposições Constitucionais Transitórias, a fim de efetivar o direito à memória e à verdade histórica e promover a reconciliação nacional (BRASIL, 2014). Assim, merece destaque o impacto causado pela sentença da CorteIDH na criação da CNV.

O Estado brasileiro, por sua vez, argumentou que a tipificação do delito de desaparecimento forçado no ordenamento interno brasileiro encontra-se sujeita ao exame do Poder Legislativo, mediante dois projetos de lei: a) o de $n^{\circ} 4.038 / 08$, apresentado em setembro de 2008, cujo artigo 33 define o desaparecimento forçado como crime contra a humanidade e b) o de $\mathrm{n}^{\mathrm{o}} 301 / 07$, cujo artigo 11 também tipifica o desaparecimento forçado ${ }^{21}$. Além disso, o Estado brasileiro, em seu informe sobre o cumprimento da sentença, salientou que o Decreto Legislativo que ratificaria a Convenção Interamericana sobre Desaparecimento Forçado de Pessoas, se encontrava em tramitação no Congresso Nacional (CorteIDH, 2010). O Decreto n.

21 Os dois projetos tramitam apensados para que eventualmente possam ser integrados em uma só proposta legislativa. Os projetos de lei continuam em análise até agosto de 2019 (data de conclusão desse trabalho) ainda que um requerimento de regime de urgência tenha sido proposto em 2016 em relação aos projetos de lei $301 / 07$ e 4028/08. 
8.766 que internaliza a Convenção Interamericana no Brasil foi promulgado em 11 de maio de 2016.

Em resposta aos argumentos apresentados pelo Estado brasileiro, a Corte afirmou que o Estado não deve limitar-se a promover o projeto de lei, mas assegurar sua pronta promulgação e entrada em vigor, de acordo com os procedimentos estabelecidos no ordenamento jurídico interno. Enquanto cumpre essa medida, o Estado deverá adotar ações que garantam o efetivo julgamento $\mathrm{e}$, se for $\mathrm{o}$ caso, punição dos fatos constitutivos do desaparecimento forçado, através dos mecanismos existentes no direito interno (CorteIDH, 2010).

Em relação à legislação brasileira, o Projeto de Lei no 4038/08, apensado ao de $\mathrm{n}^{\circ}$ 301/07, possuem o objetivo de tipificar o crime de desaparecimento forçado e definir condutas que constituem crimes internacionais, de violação do Direito Internacional Humanitário e de Direito Internacional dos Direitos Humanos e estabelece normas para a cooperação judiciária com o Tribunal Penal Internacional. A pendência na aprovação do projeto e as questões processuais que suscita e que devem, portanto, ser resolvidas para que a lei seja aprovada, não favorece a eficácia dos instrumentos de proteção internacional no plano nacional e limita as possiblidades de o Brasil respeitar totalmente suas obrigações internacionais (JARDIM, 2012, p. 10).

A sentença da Corte Interamericana no caso Guerrilha do Araguaia apresenta considerável impacto na atividade legislativa brasileira, sobretudo na necessidade de tipificar o crime de desaparecimento forçado.

Além dessa omissão legislativa, outro impasse para discussão da temática continua sendo a Lei de Anistia, promulgada no Brasil ainda em 1979. Embora notadamente contrária aos princípios da Convenção Interamericana de Direitos Humanos (PAYNE, ABRÃO \& TORELLY, 2011, p. 119) - da qual o Brasil é país ratificante -, a referida lei foi reafirmada como constitucional pelo Supremo Tribunal Federal nos processos de Arguição de Descumprimento de Preceito Fundamental $(\mathrm{ADPF})^{22}$. A ADPF $\mathrm{n}^{\mathrm{0}}$ 153, protocolada em 2008 e a ADPF $\mathrm{n}^{\mathbf{0}} 320$

22 A Arguição de Descumprimento de Preceito Fundamental (ADPF) é um instrumento de defesa de interesse geral, destinado à proteção judiciária. Destina-se a prevenir ou reparar lesão contra os preceitos fundamentais da Constituição. O instrumento também pode ser utilizado para solver controvérsias constitucionais sobre a constitucionalidade do direito federal, estadual e municipal. Ainda, a lei que 
protocolada em 2014, estão apensadas à ADPF 153 por tratarem da mesma matéria.

Em 2018, a CorteIDH publicou a sentença relativa ao caso Herzog e outros contra Brasil, que trata sobre o assassinato do jornalista brasileiro Vladimir Herzog por parte de agentes do DOI/CODI, em outubro de 1975. A CorteIDH declarou responsável o Estado do Brasil pela violação dos direitos às garantias judiciais e à proteção judicial e também em relação ao não cumprimento dos princípios da Convenção Interamericana para Prevenir e Punir a Tortura (CIPST), em detrimento de Zora, Clarice, André e Ivo Herzog - familiares do jornalista morto (CorteIDH, 2018).

Essas violações se deram como consequência da falta de investigação, julgamento e punição dos responsáveis pela tortura e assassinato de Vladimir Herzog, cometidos em um contexto sistemático e generalizado de ataques à população civil, assim como pela aplicação da Lei de Anistia (Lei $n^{\circ}$ 6683/79) e de outros excludentes de responsabilidade proibidos pelo Direito Internacional em casos de crimes contra a humanidade. Adicionalmente, a Corte considerou que o Estado é responsável pela violação do direito de conhecer a verdade em detrimento de seus familiares, em virtude de não haver esclarecido judicialmente os fatos violatórios do presente caso e de não haver apurado as responsabilidades individuais respectivas em relação com a tortura e o assassinato de Vladimir Herzog (CorteIDH, 2018).

Por fim, a Corte ordenou ao Estado a adoção de diversas medidas de reparação, como: i) reiniciar, com a devida diligência, a investigação e o processo penal cabíveis pelos fatos ocorridos em 25 de outubro de 1975, para identificar, processar e, caso seja pertinente, punir os responsáveis pela tortura e morte de Vladimir Herzog, em atenção ao caráter de crime contra a humanidade desses fatos e às respectivas consequências jurídicas para o Direito Internacional; (ii) adotar as medidas mais idôneas, conforme suas instituições, para que se reconheça, sem exceção, a imprescritibilidade dos crimes contra a humanidade e internacionais; (iii) realizar um ato público de reconhecimento de responsabilidade internacional pelos fatos do

disciplina a ADPF (Lei n ${ }^{\circ}$ 9.882/99) estabelece, expressamente, a possibilidade de sua aplicação de normas anteriores à Constituição [como é o caso da Lei de Anistia], permitindo que controvérsias relevantes afetas ao direito pré-constitucional sejam solvidas pelo STF com eficácia geral e efeito vinculante (MENDES et.al., 2009, p. 1208-1209). 
presente caso, em desagravo à memória de Vladimir Herzog ; (iv) publicar a Sentença em sua integridade; e (v) pagar os montantes fixados na Sentença, a título de danos materiais e imateriais e de reembolso de custas e gastos (CorteIDH, 2018).

\subsection{0 desaparecimento forçado na jurisprudência estrangeira}

Nesse mesmo sentido de impasses causados por leis latinoamericanas que defendem a anistia, o entendimento da Corte Suprema de Justiça do Chile, em decisão no ano de 1998, pode ser considerado positivo, uma vez que se decidiu que a Lei de Anistia (Decreto Ley $\mathbf{n}^{\mathbf{0}}$ 2191, de 1978) não poderia ser aplicada aos casos de violações de direitos humanos. A medida permitiu que uma série de investigações anteriormente barradas pudessem ter prosseguimento. Além disso, declarou-se que o crime de desaparecimento forçado é permanente e contínuo até que os corpos das vítimas sejam localizados.

Terminada a ditadura no Chile em 1990 e até setembro de 1998, a regra geral chilena foi a aplicação plena da Lei de Anistia. Em contrapartida, e positivamente, uma das exceções ocorreu em uma sentença em 1993, de um tribunal de primeira instância. A condenação de dois suboficiais e de um civil descartou as exceções de anistia e prescrição com base na natureza dos tipos penais, afirmando que "não apenas os efeitos se mantém com posterioridade à sua consumação; mas também que o delito como tal se mantém em forma constante em este estado de consumação" (NEIRA, 2011, p. 290). Entretanto, a mudança mais significativa em relação à aplicação da anistia chilena se evidencia em 1998, quando a Corte Suprema de Justiça do Chile determinou que, para excluir definitivamente uma causa com base na anistia, deveriam encontrar-se estabelecidas as circunstâncias do desaparecimento da vítima e determinada a identidade daqueles que participaram criminalmente (NEIRA, 2011, p. 292).

Segundo os dados fornecidos pela Corte Suprema de Justiça do Chile em 2014, haviam aproximadamente mil casos abertos, 72 deles relativos a denúncias de tortura. Até outubro de 2018, 279 pessoas haviam 
sido declaradas culpadas em julgamentos e 75 cumpriam penas de prisão. Em maio de 2014, 75 ex-agentes da Direção de Inteligência Nacional (DINA), a polícia secreta do governo Pinochet, foram condenados a penas entre 13 e 14 anos de prisão em relação com o desaparecimento forçado, em 1974, do estudante Jorge Grez Aburto (EL PAÍS, 2015).

Em 2005, a Corte Suprema de Justiça da Nação (CSJN) da Argentina também declarou a inconstitucionalidade das leis de Ponto Final (23.492) e de Obediência Devida (23.521), que impediam a punição dos crimes contra a humanidade cometidos pelo Estado entre 1975 e 1983. Essa decisão judicial é o corolário de um processo de quase três décadas contra a impunidade liderada por movimentos sociais de promoção dos direitos humanos (GUEMBE, 2005, p. 121).

O ano de 2005 também foi o ano da declaração de uma importante sentença publicada pelo Supremo Tribunal Espanhol, que condenou o militar argentino Adolfo Scilingo, ex-capitão da Marinha, a seiscentos e quarenta anos de prisão por delitos de lesa humanidade, pelo cometimento de atos de assassinato, detenção ilegal e torturas (AUDIENCIA NACIONAL, 2005). A sentença Scilingo é uma mostra dos obstáculos que uma jurisdição de caráter nacional deve superar para que se produza uma condenação por crimes contra a humanidade. Entretanto, pode ser considerada como um exemplo do empenho dos órgãos judiciais para alcançar que os crimes de lesa humanidade não fiquem estagnados como um direito inaplicável ou simbólico (CALDERÓN, 2005, p. 110). Além disso, também impede que a circunstância de "obediência devida" (de uma ordem manifestamente ilícita) possa ser aplicada como uma excludente de responsabilidade penal em relação aos crimes contra a humanidade.

Os avanços dos últimos anos ocorreram em sintonia com os processos desenvolvidos em outros países da região sul do continente sulamericano. O Chile passa por processos similares aos da Argentina, com características próprias de sua dinâmica política e social. Embora na retaguarda, o Uruguai começa a repensar algumas questões relacionadas com os direitos das vítimas e a tomar medidas nesse sentido (GUEMBE, 2005, p. 137).

No mesmo sentido desses avanços da jurisprudência latinoamericana, a sentença proferida pela Corte Italiana em relação às atividades exercidas em território sul-americano durante a Operação Condor também pode ser incluída como parte desse novo movimento de decisões judiciais internacionais e estrangeiras que desafiam a aplicação das leis de anistia e 
que questionam os limites jurisdicionais (tanto territoriais quanto pessoais) de sua aplicação.

As sentenças internacionais e estrangeiras recentes referentes às violações de direitos humanos como o desaparecimento forçado, via de regra praticadas por autoridades estatais durante o período ditatorial, trazem à tona fatos, informações e narrativas omitidas no período em que tais violações foram perpetradas assim como nos anos imediatamente posteriores ao fim dos regimes.

Argumenta-se que as sentenças trazem, além da longamente esperada reparação judicial às famílias das vítimas (e em alguns casos também informações sobre os fatos que ocasionaram a morte e a localização dos corpos das vítimas), informações valiosas sobre as práticas do período - gerando assim fonte documental de valor incalculável de respeito aos direitos à verdade e à memória.

\section{Jurisprudência recente sobre desaparecimento forçado: uma questão de memória}

A complexidade do desaparecimento forçado de pessoas tanto em relação a sua conceituação jurídica, quanto ao seu tratamento nas esferas política, jurídica, social, pública e privada, gera uma necessidade de aproximação de atores nacionais e internacionais. Em razão de seu caráter multifacetado, esse fenômeno priva de direitos não só a vítima do desaparecimento, mas seus familiares, a sociedade e a humanidade como um todo, na medida em que, para além das violências cometidas contra o desaparecido e seus familiares, retira a pessoa da convivência e existência no mundo (PERRUSO, 2010, p. 152).

Diante disso, a jurisprudência internacional e estrangeira, nas recentes decisões que vêm sendo tomadas em relação aos crimes cometidos pelas ditaduras do Cone Sul, incluindo decisões sobre a Operação Condor possuem um papel fundamental não apenas em seu sentido jurídico, mas, principalmente, nos reflexos mais amplos que geram para a sociedade latino-americana. As sentenças não apenas cumprem sua função formal de aplicar os princípios e convenções dos sistemas de proteção aos direitos 
humanos; mas também devem atuar no sentido de evitar lacunas em sua interpretação e aplicabilidade. Se há histórico de violações de direitos, a reparação jurídica é esperada independentemente de critérios temporais de imputação de culpabilidade, para atuar no sentido de que violações e cerceamentos de direitos fundamentais sejam descobertos, discutidos e enfrentados.

Argumenta-se que a impunidade constituiu a pior herança que recebemos da ditadura e contabilizou a maior dívida da democracia (TELES, 2007, p. 1). A proposta aqui apresentada é a de que não devemos entender impunidade apenas em seu sentido estrito, mas também compreendê-la como um primeiro passo para o pleno acesso à justiça, ao contraditório (uma vez que o discurso vitorioso dos militares foi e continua sendo um entrave para discussões sobre ditaduras e direitos humanos) e ao passado, de forma a acessar documentos, depoimentos e alcançar, da melhor e mais efetiva forma possível, os fatos que geraram as violações de direitos humanos.

Ainda hoje não foram apuradas todas as responsabilidades referentes aos sequestros, torturas, mortes e desaparecimentos forçados cometidos pelos agentes do Estado brasileiro entre 1964 e 1985. Há mais de 50 anos, familiares buscam restos mortais dos que ainda não foram sepultados. Passado o tempo e após a promulgação de leis de reparação das vítimas e de seus familiares e da própria finalização dos trabalhos da Comissão Nacional da Verdade, que teve como objetivo apurar e denunciar os crimes cometidos pelo governo ditatorial; mantém-se o silêncio e impede-se o acesso total aos arquivos (que ainda restam) do período. $\mathrm{O}$ caso brasileiro evidencia que lacunas em relação aos direitos à memória e à verdade permanecem latentes na América Latina embora as conquistas devam ser ressaltadas.

Halbwachs afirma que para que a nossa memória se aproveite da memória dos outros, não basta que estes nos apresentem seus testemunhos: também é preciso que ela não tenha deixado de concordar com as memórias deles e que existam muitos pontos de contato entre umas e outras para que a lembrança que nos fazem recordar venha a ser reconstruída sobre uma base comum (1990, p. 39). É preciso que esta reconstrução funcione a partir de dados ou de noções comuns que estejam em nosso espírito e também no dos outros, porque elas estão sempre passando destes para aquele e vice-versa, o que será possível somente se tiverem feito parte e continuarem fazendo parte de uma mesma sociedade, de um mesmo grupo 
(HALBWACHS, 1990, p. 39). Somente assim podemos compreender que uma lembrança é ao mesmo tempo reconhecida e reconstruída.

A memória é resultado do movimento do sujeito no ato da memorização, como também é ação dos diversos grupos sociais em suas histórias, o passado e presente. $\mathrm{O}$ autor compreende a memória coletiva como um elemento essencial para a vivência social por realizar reinvenções do passado que fornecem fundamentos para que seres humanos interpretem e vivenciem o presente e, a partir de então, visualizem a construção de projetos capazes de modificar o futuro. Halbwachs, distancia a memória coletiva de uma imposição, de uma forma específica de dominação e acentua as funções positivas desempenhadas pela memória comum - e, entre elas, a de reforçar a coesão social (HALBWACHS, 1990, p. 39).

Para que a memória tenha significado para o ser humano, este deve esquecer a maior parte do que viu, ouviu e experimentou. Essa é uma condição básica do lembrar. Além de classificar, combinar e destacar lembranças, o ser humano deve poder esquecer (PADRÓS, 2004, p. 3). O esquecimento deve ser uma opção, principalmente no que diz respeito a experiências traumáticas como a tortura, o sequestro, os expurgos, os fuzilamentos simulados, os desaparecimentos, as prisões, o exílio, o insílio, o desexílio, as detenções clandestinas, o "botim de guerra", as execuções e outras modalidades de violência repressiva estatal.

Inegavelmente, os regimes de exceção, com as suas conhecidas motivações repressivas de controle, de censura e de enquadramento de memórias e de consciências, são indutores de um "esquecimento organizado" (PADRÓS, 2004, p. 4). Tão desafiador e complexo quanto entender essa dinâmica é compreender a lógica de controle e de supressão, oficial ou não, na reconversão para tempos de democracia. De certa forma, é isso que está em questão na América Latina pós-ditaduras. As leis de anistia são um exemplo dessa imposição e de uma tentativa de "normalização" da sociedade. Para os governos militares transicionais, a pacificação dos conflitos sociais pressupunha o esquecimento e a equiparação dos crimes cometidos pelos atores nas várias frentes, estatais (oficiais) e de oposição em uma medida de "saneamento moral" (VINYES, 2009).

Diante dessa compreensão acerca das memórias coletivas, surgiram no cenário público nas décadas de 1960 e 1970 novos grupos de pessoas: os familiares de desaparecidos (PERRUSO, 2010, p. 137). Juntos, eles reivindicam o reconhecimento da existência desse novo "sujeito 
social" (o desaparecido); buscam saber a verdade dos fatos e o paradeiro de seus entes desaparecidos; demandam justiça e reparação frente aos atos cometidos pelo Estado ou com sua anuência. Na Argentina, por exemplo, o desaparecido passou a "existir" como uma noção de pessoa que, por ter surgido de um estado de terror impensável é, até o presente, essencialmente paradoxal (CATELA, 2001, p. 202-203). Sua simples enunciação obriga a se realizar uma passagem dos anos 70 até a atualidade e mapear a posição de quem a emite, permitindo acesso e reflexão sobre o passado recente.

As sentenças, de certa forma, recuperam os fatos que causaram o desaparecimento e o tornam centro das discussões. A discussão sobre os desaparecimentos forçados, tanto no âmbito de suas definições e conceituações; como em relação à discussão de seu modus operandi, e, principalmente, em relação às sentenças que definem seus responsáveis e sua reparação, leva o tema a um protagonismo que, mesmo tardio, é imprescindível. É relevante que, mesmo que em 2019, sejam publicadas sentenças que condenem os responsáveis e exponham os crimes cometidos durante as ditaduras. Observe-se, por exemplo, que mesmo antes da publicação e divulgação na íntegra da sentença do Tribunal de Apelação de Roma, a grande mídia internacional já havia publicado seus efeitos - o que faz com que toda a sociedade tenha contato com seus resultados.

Além disso, ressalte-se que, de modo geral, as sentenças da Corte Interamericana de Direitos Humanos enfatizam o acesso ao passado, a partir da defesa aos direitos à memória e à verdade ${ }^{23}$. No caso Goiburú e

23 No mesmo sentido, a antiga Comissão de Direitos Humanos das Nações Unidas, no Conjunto de Princípios atualizados para a proteção e a promoção dos direitos humanos mediante a luta contra a impunidade de 2005, estabeleceu, inter alia, que: a) cada povo tem o direito inalienável de conhecer a verdade sobre os acontecimentos sucedidos no passado em relação à perpetração de crimes aberrantes (princípio 2); b) o Estado deve preservar os arquivos e outras provas relativas a violações de direitos humanos e facilitar o conhecimento de tais violações, como medida encaminhada a preservar do esquecimento a memória coletiva e, em particular, evitar que surjam teses revisionistas e negacionistas (princípio 3); c) independentemente das ações que possam interpor perante a justiça, as vítimas e suas famílias têm o direito imprescritível de conhecer a verdade acerca das circunstancias nas quais se cometeram as violações e, em caso de falecimento ou desaparecimento, acerca do destino da vítima (princípio 4), e d) incumbe aos Estados adotar as medidas adequadas, incluídas as medidas necessárias para garantir o funcionamento independente e eficaz do poder judicial, para fazer efetivo o direito a saber. As medidas apropriadas para assegurar esse direito podem incluir processos não judicias que complementem a função do poder judicial. Em todo caso, os Estados devem garantir a apresentação de arquivos relativos a violações de direitos humanos e a possibilidade de consultá-los. Cf. Conjunto de Princípios atualizados para a proteção e a promoção dos direitos humanos mediante a luta contra a impunidade (E/CN.4/2005/102/Add.1), de 8 de fevereiro de 2005 (CIDH, 2010, p. 76). 
outros contra Paraguai, por exemplo, levando em consideração as atribuições que o incumbem de velar pela melhor proteção dos direitos humanos e dada a natureza do caso, a Corte estimou que ditar uma sentença na qual se determine a verdade dos fatos e todos os elementos do assunto, assim como suas consequências correspondentes, constitui uma forma de contribuir com a preservação da memória histórica, da reparação para os familiares das vítimas e, também, contribuir para evitar que fatos similares se repitam (CorteIDH, 2006).

Em 2004, a Corte julgou o caso 19 Comerciantes contra Colômbia. Na sentença, estabelece, a título de reparações, que o Estado colombiano deveria investigar e punir os responsáveis por tais violações, além de realizar uma busca séria no sentido de localizar os restos mortais dos 19 desaparecidos em 1987, erigir um monumento sua memória e inaugurá-lo em cerimônia pública com a presença dos familiares, oferecer tratamento de saúde e psicológico aos familiares das vítimas que nele expressem interesse e que o Estado colombiano declare em ato público sua responsabilidade internacional pelo caso (CorteIDH, 2004). Ressalte-se, no entanto, que o caso colombiano, embora trate de desaparecimento forçado e de responsabilização do Estado, não ocorreu no contexto de uma ditadura civil-militar e sim da atuação de membros das Forças Armadas colombianas e de grupos paramilitares que atuavam na região dos desaparecimentos. Argumenta-se, contudo, que o papel da sentença, em termos de reparação jurídica e do direito à memória é essencialmente o mesmo dos casos em análise neste artigo.

No caso Gomes Lund e outros (Guerrilha do Araguaia) contra Brasil, a Corte conclui que a jurisprudência, o costume e a doutrina internacionais consagram que nenhuma lei ou norma de direito interno, tais como as disposições acerca da anistia, as normas de prescrição e outras excludentes de punibilidade, deve impedir que um Estado cumpra a sua obrigação inalienável de punir os crimes contra a humanidade por serem insuperáveis nas existências de um indivíduo agredido, nas memórias dos que compõem seu círculo social e por gerações de toda a humanidade (CorteIDH, 2010).

$\mathrm{Na}$ sentença do caso Vladimir Herzog contra Brasil, por fim, a Corte constatou que, com efeito, o Brasil envidou diversos esforços para atender ao direito à verdade de pessoas próximas à vítima e de seus familiares e também da sociedade em geral. A Corte avaliou positivamente a criação e os respectivos relatórios da Comissão Especial de Mortos e 
Desaparecidos Políticos, bem como da Comissão Nacional da Verdade ${ }^{24}$. Entretanto, a verdade sobre os fatos do passado que possa resultar desse tipo de esforço, segundo a CorteIDH, de nenhuma forma substitui ou dá por atendida a obrigação do Estado de estabelecer a verdade e assegurar a determinação judicial de responsabilidades criminais individuais. A CorteIDH apurou responsabilidade por negligência na investigação da morte de Vladimir Herzog e julgou necessário que o Estado brasileiro realize um ato público de reconhecimento de responsabilidade internacional pelos fatos do caso em tela, em desagravo à memória de Vladimir Herzog (CorteIDH, 2018).

A partir do exposto e do que se depreende das sentenças estrangeiras e internacionais que buscam reparação jurídica para as vítimas e familiares das vítimas de violações de direitos humanos por regimes ditatoriais, argumenta-se a criação e documentação de espaços em que disputas de memórias acontecem; em que lugares de memória são criados; e em que a memória dos desaparecimentos e dos desaparecidos é reconhecida e reconstruída.

Considerações Finais

O passado ditatorial enfrentado por muitos Estados latinoamericanos durante a segunda metade do século $\mathrm{XX}$, marcado por violações aos direitos humanos, dentre elas a prática de desaparecimentos forçados, configura-se como uma preocupação da justiça internacional e estrangeira. Longe de ser uma questão dada por acabada e longe de interessar apenas os Estados ou as vítimas diretas dessas práticas repressivas, a temática deve ser tratada como de interesse e relevância internacionais, já que seu conteúdo ultrapassa apenas a questão punitiva dos crimes, mas trata-se de acessar e compreender o passado, buscando efetivar a garantia de proteção dos direitos humanos celebrados em diversos tratados internacionais - dos quais muitos Estados da América Latina são ratificantes.

A jurisprudência internacional e estrangeira refletem a preocupação em relação aos graves crimes que violam a humanidade; o desafio do combate à impunidade, sobretudo de chefes de Estado e agentes da repressão; o movimento de internacionalização dos direitos humanos; e 
a redefinição da noção clássica de soberania absoluta do Estado, já que as graves violações a direitos humanos perpetradas no âmbito interno de um Estado passam a demandar uma resposta internacional (PIOVESAN, 2013, p. 312). É entendimento pacífico na normativa internacional, que o legado de graves e sistemáticas violações de direitos humanos, como o deixado pela ditadura brasileira, gera obrigações aos Estados, em relação às vítimas e às sociedades, na passagem ou retorno à democracia (MEZAROBBA, 2014, p. 197). Um desses deveres é exatamente o de estabelecer os fatos, implícito em distintos documentos da legislação humanitária internacional, promovendo um amplo e irrestrito acesso ao passado.

As decisões judiciais internacionais e de direito comparado referidas neste artigo claramente demonstram o compromisso dos sistemas internacionais de proteção de direitos humanos em levar adiante o dever jurídico de investigar e sancionar as violações de direitos humanos usualmente definidas como crimes contra a humanidade, dentre elas a tortura, as execuções sumárias e o desaparecimento forçado de pessoas. Os sistemas regionais de proteção, dentre os quais desponta a atuação do o sistema interamericano - aqui descrita no caso específico dos desaparecimentos forçados - têm papel fundamental em romper com o legado de impunidade associado à generalizadas violações de direitos humanos por ação ou omissão do Estado. O papel das sentenças condenatórias sobre os desaparecimentos forçados, tomados aqui a partir da atuação transnacional da Operação Condor, para além de um viés punitivista, enfatizam dois aspectos principais: a reparação jurídica (para vítimas ou seus familiares) e o direito à memória.

\section{Referências}

A prisão de Augusto Pinochet: 20 anos do caso que transformou a Justiça Internacional. El País. Santiago, Chile, 27 de outubro de 2018. Disponível em: https://brasil.elpais.com/brasil/2018/10/16/internacional/1539652824_848459.html

ABRÃO, Paulo; TORELLY, Marcelo D. Mutações do conceito de anistia na Justiça de Transição brasileira. A terceira fase de luta pela anistia. Revista de Direito Brasileira, RDBras, 3, 2012, pp. 357-379. 
ÁGUILA, Gabriela; ALONSO, Luciano. Presentación. Ayer. Revista de Historia Contemporánea. 107/2017 (3). Madrid, 2017, pp. 13-19.

BAUER, Caroline Silveira. Brasil e Argentina: ditaduras, desaparecimentos e políticas de memória. $2^{\text {a }}$ edição - Porto Alegre: Medianiz, 2014.

BOBBIO, Norberto; MATTEUCCI, Nicola; PASQUINO, Gianfranco. Dicionário de política. Brasília: Editora Universidade de Brasília, 11ª edição, 1998.

BRASIL. Lei $n^{o}$ 12.528. Promulgada em 18 de novembro de 2011. Disponível em: http://www.planalto.gov.br/ccivil_03/_ato2011-2014/2011/lei/112528.htm

BRASIL. COMISSÃO NACIONAL DA VERDADE. Relatório. Brasília: CNV, 2014. Disponível em: http://cnv.memoriasreveladas.gov.br/

CALDERÓN, Silvia Mendoza. La reciente aplicación de los crímenes de lesa humanidad en España: el Caso Scilingo. REJ - Revista de Estudios de la Justicia. Facultad de Derecho, Universidad de Chile. No 6, año 2005, pp. 85-113. Disponível em: http://web.derecho.uchile.cl/cej/rej6/CASO_SCILINGO_SMC\%20_4_.pdf

CALVEIRO, Pilar. Poder e desaparecimento: os campos de concentração na Argentina. Tradução Fernando Correa Prado. São Paulo: Boitempo, 2013.

CANÇADO TRINDADE, Antonio Augusto. A Humanização do Direito Internacional. Belo Horizonte: Del Rey, 2006.

CATELA, Ludmila da Silva. Situação limite e memória: reconstrução do mundo dos familiares de desaparecidos da Argentina. São Paulo: Hucitec/Anpocs, 2001.

Chile: La Ley de Amnistía mantiene vivo el legado de Pinochet. El País, Chile, 11 de setembro de 2015.2 Disponível em: https:/elpais.com/internacional/2015/09/11/actualidad/1441979718_729682.html

COMBLIN, Joseph. A ideologia da segurança nacional: o poder militar na América Latina. Rio de Janeiro: Civilização Brasileira, 1978.

CORTE INTERAMERICANA DE DIREITOS HUMANOS. Caso Velásquez. Rodríguez vs. Honduras. Sentença de 29 de julho de 1988. Série C, n. 4. Disponível em: http://www.corteidh.or.cr/docs/casos/articulos/seriec_04_por.doc

CORTE INTERAMERICANA DE DIREITOS HUMANOS. Caso Fairén Garbi y Solís Corrales vs. Honduras. Sentença de 15 de março de 1989. Série C, n. 6. Disponível em: http://www.corteidh.or.cr/docs/casos/articulos/seriec_06_esp.pdf 
CORTE INTERAMERICANA DE DIREITOS HUMANOS. Caso 19 Comerciantes vs. Colombia. Sentença de 5 de julho de 2004. Série C, n. 109. Disponível em: http://www.corteidh.or.cr/docs/casos/articulos/seriec_109_esp.pdf

CORTE INTERAMERICANA DE DIREITOS HUMANOS. Caso Goiburú y otros vs. Paraguay. Sentença de 22 de setembro de 2006. Série C, n. 153. Disponível em: http://www.corteidh.or.cr/docs/casos/articulos/seriec_153_esp.pdf

CORTE INTERAMERICANA DE DIREITOS HUMANOS. Caso Gomes Lund e outros (Guerrilha do Araguaia) vs. Brasil. Sentença de 24 de novembro de 2010. Série C, n. 209. Disponível em: http://www.corteidh.or.cr/docs/casos/articulos/seriec_219_por.pdf

CORTE INTERAMERICANA DE DIREITOS HUMANOS. Caso Gelman vs. Uruguai. Sentença de 24 de fevereiro de 2011. Série C, n. 221. Disponível em: http://www.corteidh.or.cr/docs/casos/articulos/seriec_221_esp1.pdf

CORTE INTERAMERICANA DE DIREITOS HUMANOS. Caso Herzog e outros vs. Brasil. Sentença de 15 de março de 2018. Série C, n. 353. Disponível em: http://www.corteidh.or.cr/docs/casos/articulos/seriec_353_por.pdf

FERNANDES, Ananda Simões. A reformulação da Doutrina de Segurança Nacional pela Escola Superior de Guerra no Brasil. Antíteses, vol. 2, n. 4, jul./dez. de 2009, pp. 831-856. Disponível em: http://www.uel.br/revistas/uel/index.php/antiteses/article/viewFile/2668/3937

Fundación Martin Almada. Disponível em: http://www.martinalmada.org/

GUEMBE, María José. Reabertura dos processos pelos crimes da ditadura militar Argentina. Sur, Rev. int. direitos humanos, vol.2 no.3. São Paulo Dec. 2005. Disponível em: http://www.scielo.br/pdf/sur/v2n3/en_a08v02n3.pdf

HALBWACHS, Maurice. A Memória coletiva. Vértice, 1990.

HENKIN, Louis. International law: politics, values and principles. Boston: Martinus Nijhoff, 1990.

Italian Court jails 24 over South American Operation Condor. The Guardian, Itália, Palermo, 9 de julho de 2019. Disponível em: https://www.theguardian.com/world/2019/jul/08/italian-court-jails-24-over-southamerican-operation-condor?CMP=Share_iOSApp_Other

KENICKE, Pedro Henrique Gallotti. O Estatuto do Estrangeiro e a Lei de Migrações: entre a doutrina da segurança nacional e o desenvolvimento humano. [Dissertação] Mestrado em Direito. Universidade Federal do Paraná. 2016. 
MARMONTEL, Leonardo. Operação Condor: A internacionalização do terror. Estudios Avanzados 21 (Santiago, jun. 2014): 111-136.

MENDES, Gilmar F.; COELHO, Inocêncio M.; BRANCO, Paulo Gustavo G. Curso de Direito Constitucional. $4^{\text {a }}$ edição. São Paulo: Saraiva, 2009.

MENDOZA ESCOBAR, Ana María. Nunca Más (Never Again). Towards a jurisprudential cross-fertilization for the prosecution of the enforced disappearances at the ICC. Master Thesis. Faculty of Law. Lund University - Sweden. 2018.

MEZAROBBA, Glenda. A verdade e o processo de acerto de contas do Estado brasileiro com as vítimas da ditadura e a sociedade. In: PRADO, Inês Virginia; PIOVESAN, Flávia. (org.). Direitos humanos atual. Rio de Janeiro: Elsevier Editora, 2014.

NEIRA, Karinna Fernández. La jurisprudencia de la Corte Suprema Chilena, frente a las graves violaciones contra los derechos humanos cometidos durante la dictadura militar. In: GOMES, Luiz Flávio; MAZZUOLI, Valerio de Oliveira (org.). Crimes da ditadura militar: uma análise à luz da jurisprudência atual da Corte Interamericana de direitos humanos: Argentina, Brasil, Chile, Uruguai. São Paulo: Editora Revista dos Tribunais, 2011.

Operazione Condor, 24 ergastoli a ex capi di Stato e 007 per 23 italiani uccisi. Il Fatto Quotidiano, Itália, 9 de julho de 2019. Disponível em: https:/www.ilfattoquotidiano.it/2019/07/08/operazione-condor-24-ergastoli-a-excapi-di-stato-e-007-sudamericani-per-23-italiani-desaparecidos/5310162/

Operazione Condor, quando il Sudamerica diventò il subcontinente dei dittatori. $\mathrm{La}$ Repubblica, Itália, 8 de julho de 2019. Disponível em: https://www.repubblica.it/cronaca/2019/07/08/news/operazione_condor_quando_il_ sudamerica_divento_il_subcontinente_dei_dittatori-230737685/

ORGANIZAÇÃO DOS ESTADOS AMERICANOS. Convenção Interamericana sobre o Desaparecimento Forçado de Pessoas. 9 de junho de 1994. Disponível em: https://www.cidh.oas.org/basicos/portugues/k.Desaparecimento.htm

PADRÓS, Enrique Serra. Memória e esquecimento das ditaduras de Segurança Nacional: os desaparecidos políticos. História em revista, v.10, 2004. Disponível em: https://periodicos.ufpel.edu.br/ojs2/index.php/HistRev/article/view/11658/7488

PADRÓS, Enrique Serra. Como el Uruguay no hay... Terror de Estado e Segurança Nacional. Uruguai (1968-1985): do Pachecato à Ditadura Civil-Militar. Porto Alegre: UFRGS, 2005. 850 f. Tese (Doutorado em História) - Programa de 
Pós-Graduação em História, Universidade Federal do Rio Grande do Sul, Porto Alegre, 2005.

PAYNE, Leigh A.; ABRÃO, Paulo; TORELLY, Marcelo D. A Anistia na Era da Responsabilização: O Brasil em perspectiva internacional e comparada. Brasília: Ministério da Justiça, Comissão de Anistia; Oxford: Oxford University, Latin American Centre, 2011.

PERRUSO, Camila Akemi. O desaparecimento forçado de pessoas no Sistema Interamericano de Direitos Humanos - Direitos Humanos e Memória. Dissertação de Mestrado, Faculdade de Direito da Universidade de São Paulo, 2010.

PERRUSO, Camila Akemi. O Brasil e o desaparecimento forçado de pessoas. Nomos Revista do Curso de Mestrado em Direito da UFC, v. 30 n. 1 (2010): jan./jun. 2010. Disponível em: http://periodicos.ufc.br/nomos/article/view/1236

PIOVESAN, Flávia. Direitos humanos e o Direito Constitucional Internacional. $14^{\mathrm{a}}$ edição, revista e atualizada. São Paulo: Saraiva, 2013.

PIOVESAN, Flávia. Direitos humanos e justiça internacional: um estudo comparativo dos sistemas regionais europeu, interamericano e africano. $5^{\mathrm{a}}$ edição revista, ampliada e atualizada. São Paulo: Saraiva, 2014.

Sentencia de la Audiencia Nacional (España), de 19 de abril de 2005. Disponível em: http://www.derechoshumanos.net/jurisprudencia/2005-04-19-AN-(Scilingo)Sentencia-condenatoria.htm

TELES, Janaina de Almeida. Ditadura e Repressão. Paralelos e distinções entre Brasil e Argentina. Revista de Sociedad, Cultura y Política en América Latina. Vol. $3, n^{\circ} 4,2014$.

VERBITSKY, Horacio. El Vuelo. Una forma cristiana de muerte. Grupo Editorial Planeta: Buenos Aires, 1995.

VINYES, Ricard. Sobre víctimas y vacíos; ideologías y reconciliaciones; privatizaciones e impunidades. 2009. Mimeo. 
RECEBIDO EM: 30/08/2019 APROVADO EM: 03/10/2019 